\title{
Kinetic Model Comparison for Biogas Production from Poultry Manure and Banana Peels
}

\author{
Kenechi Nwosu-Obieogu ${ }^{1 \star}$, Felix Osarumehnsen Aguele ${ }^{1}$, Austin Onyenwoke ${ }^{2}$, Kayode Adekunle ${ }^{1}$
}

\begin{abstract}
${ }^{1}$ Chemical Engineering Department, Michael Okpara University of Agriculture, Umudike, NIGERIA
${ }^{2}$ Agric. and Bioresources Engineering, Michael Okpara University of Agriculture, Umudike, NIGERIA

*Corresponding Author: kenenwosuobie@yahoo.com
\end{abstract}

Citation: Nwosu-obieogu, K., Aguele, F. O., Onyenwoke, A., \& Adekunle, K. (2020). Kinetic Model Comparison for Biogas Production from Poultry Manure and Banana Peels. European Journal of Sustainable Development Research, 4(2), em0117. https://doi.org/10.29333/ejosdr/7595

\begin{tabular}{ll}
\hline ARTICLE INFO & $\begin{array}{l}\text { ABSTRACT } \\
\text { Received: } 17 \text { Nov. 2019 }\end{array} \quad \begin{array}{l}\text { This study reports the production of biogas using poultry manure and banana peels as a co-substrate, the } \\
\text { experiments were carried out in a } 20 \text { litre biodigester and incubated for } 50 \text { days at mesophilic temperature of } 34^{\circ} \mathrm{C}\end{array}$ \\
Revised: 31 Dec. 2019 & $\begin{array}{l}\text { and pH of } 6.8 . \text { The results show that the production of biogas began on the } 10^{\text {th }} \text { day with a yield of } 1.90 \mathrm{ml} \text { and } \\
\text { increased continuously to the } 20^{\text {th }} \text { day with an optimal yield of } 17.30 \mathrm{ml} \text {. Then, the yield decreased for the } \\
\text { remaining period but did not cease till the } 50^{\text {th }} \text { day. Kinetic models were used to compare biogas production at } \\
\text { the ascending limb and the exponential and first order kinetic model had a better correlation and fit. }\end{array}$
\end{tabular}

Keywords: poultry manure, banana peels, biogas, kinetic model

\section{INTRODUCTION}

Over the past fifty years, the world relied on fossil fuels for energy which is a major cause of environmental pollution and climate change thus leading to the search of alternatives sources in recent times (Ekpo \& Thomas, 2007; Imam et al., 2013). Nature's stores of fossil fuels are drastically being depleted and cannot be regenerated and the indispensable role played by energy in the development of mankind cannot be overemphasized. In a bid to proffer solution to these challenges attempts is continuously been made to generate energy that is environmentally friendly and ecologically balanced from solar, wind, hydro, biomass etc. that require huge economic value and technical power to operate. The use of biogas energy could be the one and only reliable easily available and economically feasible source of alternative and renewable source of energy which can be managed by locally available sources and simple technology (Anushiya, 2010; Budyono et al., 2010; Kaygusuz \& Kaygusuz, 2002). Sources have revealed that the largest underutilized resources for biogas production are found in agriculture and it is regarded as cheap and clean (Jorgensen, 2009; Wilawan et al., 2014; Win \& Vandamme, 2009). Handling of poultry manure and plant waste such as banana peel, plantain peel and saw dust pose a threat on the environment and has generated great pressure in many parts of the world, if not disposed properly can cause adverse environmental and health problems. Accumulation of these waste on large disposal site have posed a problem by releasing methane to the atmosphere which is powerful green house gas, also the burning of fossil fuels contributes negatively to the climate leading to catastrophic events such as storms, droughts, sea level rise and floods which is heavily being felt across the world (Budyono et al., 2010). Researchers has over the years developed biogas from various agricultural waste ranging from forage grasses, roots and tubers marine species, cattle paunch, cow dung and poultry droppings and water hyacinth (Ezeoha \& Idike, 2007; Gunaseelan, 1997; Kivais \& Mtila, 2005; Kumar, 2005; Maile \& Mucunda, 2014; Raposo et al., 2012; Singhal \& Rai, 2003; Yeole \& Renade, 1992) but not much has been done on the reaction kinetics of biogas production and analysing the process via kinetic models which reduces additional costs for continuous and repeated experiments in process selection and encourages its rapid comparison. Modified Gompertz plot has been used by (Ghatak \& Mahanta, 2014; Latinwo \& Agarry, 2015; Matheri et al., 2016) to simulate biogas production from pig waste and grass clippings, and cow dungs with plantain peel respectively and it had better correlation than the linear model. hence, the need to further analyse biogas yield using linear, exponential; zero, first and second order kinetic models to ascertain its optimal production with a better fit. This research aims at adding value to these wastes by assessing the production of biogas and its optimal yield from poultry manure and banana peels by evaluating the effect of retention time on the biogas yield and establishing the kinetic model of the process. 


\section{KINETIC MODEL FOR BIOGAS PRODUCTION}

First and second order kinetics was used to test the liner model of the equation after the kinetics of the biogas production was banana peels modelled using linear and exponential equations.

The first order kinetic model is stated as

$$
\ln \left\{\frac{y_{m}}{y_{m}-y_{t}}\right\}=k t
$$

The second order kinetic model is stated as

$$
\left\{\frac{y_{m}}{y_{m}-y_{t}}\right\}^{-1}=k t
$$

Where $y m=$ biogas yield obtained in 50 days $(\mathrm{ml} / \mathrm{g} /$ day $): y t=$ biogas yield obtained at the time $t(\mathrm{ml} / \mathrm{g} / \mathrm{day}) ; \mathrm{k}=$ biogas rate constant (l/day); $t=$ biogas production time.

With respect to the linear equation, the rate of biogas production is directly proportional to time,

$$
y=a+b t
$$

On the exponential equation, the rate of biogas production increase with the digestion time,

Where

$$
y=a+b \exp (c t)
$$

Where $y=$ the biogas production rate $(\mathrm{ml} / \mathrm{gas} / \mathrm{day}) ; t=$ the biogas production time (day); $a, b=$ constants $(\mathrm{ml} / \mathrm{g} / \mathrm{day}) ; c=$ constant ( $\mathrm{ml} / \mathrm{g} / \mathrm{day})$, c will be positive on the ascending graph of biogas production (Latinwo \& Agarry, 2015; Shitophyta \& Maryudi, 2017).

\section{MATERIALS AND METHOD}

\section{Materials}

Poultry manure used as the main substrate was obtained from a nearby farm in Enugu and banana peels used as co-substrate was obtained from banana plantation in Enugu. A 20 litres plastic container with dimensions (base: $400 \mathrm{~mm} \mathrm{X} \mathrm{230mm;} \mathrm{height:}$ $275 \mathrm{~mm}$ ) served as the digester, a 10 litres transparent plastic served as the water collector, a 20 litres plastic keg filled with water to the brim and rubber hoses about 1 meter in length and $7 \mathrm{~mm}$ inner diameter was used to convey gas from the digester to the water tank then to the water collector, the weighing balance, $\mathrm{pH}$ meter, measuring cylinder, gas measuring device and thermometer.

\section{Method}

$0.5 \mathrm{~kg}$ Poultry manure and $1 \mathrm{~kg}$ of banana peels as the co-substrate were mixed together in a container. The mixture a banana plantation was prepared by adding water to the substrate in a ratio of 1:2, for the substrate and water respectively and stirring to ensure homogeneity of the mixture before it is introduced to the digester, the cork of the plastic container was used to seal it properly to allow anaerobic digestion to effectively take place, the $\mathrm{pH}$ and temperature of the digester was maintained at 6.8 and $34^{\circ} \mathrm{C}$ respectively, gas pressure from the digester causes a variation in the water level of tube indicating a displacement and showing bubbles of gas rising to the top of the measuring tube. The biogas produced was monitored and recorded from ten to the fiftieth day in the experimental set-up. The method of gas collection is the water displacement method following Archimedes principles of floatation.

\section{RESULTS AND DISCUSSION}

Table 1 and 2 presents the proximate and ultimate analysis of the poultry manure and banana peel respectively, the ash, fixed carbon and moisture content falls within range for a good digestibility performance, According to Hills and Roberts (1981), and Latinwo and Agarry (2015), maximum performance of an anaerobic digester using diary manure as substrate is usually obtained if the C: $\mathrm{N}$ ratio of the feed mixture is between 25 to $30: 1$, the $\mathrm{C}: \mathrm{N}$ ratio of poultry manure was calculated to be $12.30: 1$, whereas that of banana peel was 21.1: 1 , hence falls within specification.

Table 1. Proximate analysis

\begin{tabular}{cccc}
\hline Substrate & Ash & FC & MC \\
\hline Poultry manure & 16.70 & 9.70 & 34.00 \\
\hline Banana peels & 1.02 & 13.83 & 9.50 \\
\hline
\end{tabular}

Table 2. Ultimate analysis

\begin{tabular}{cccccc}
\hline Substrate & C & H & N & S & 0 \\
\hline Poultry manure & 23.01 & 3.08 & 1.87 & 0.44 & 21.35 \\
\hline Banana peel & 37.93 & 4.46 & 1.8 & 0.38 & 55.37 \\
\hline
\end{tabular}


A plot of biogas yield as a function of time was shown in Figure 1, from the graph, the biogas production started on the $10^{\text {th }}$ day and increased continuously up to the $20^{\text {th }}$ day, and this coincides with the exponential phase with an optimal biogas yield of $17.30 \mathrm{ml}$. Then the yield decreased continuously for the remaining period, which signifies that the substrate is depleted of nutrients (Skarstad et al., 2003). The increase in yield with time was observed from the $10^{\text {th }}$ day to the $20^{\text {th }}$ day of production, hence this research is focused from when the substrates starts yielding biogas till its optimum production analysed with a linear and exponential model shown below.

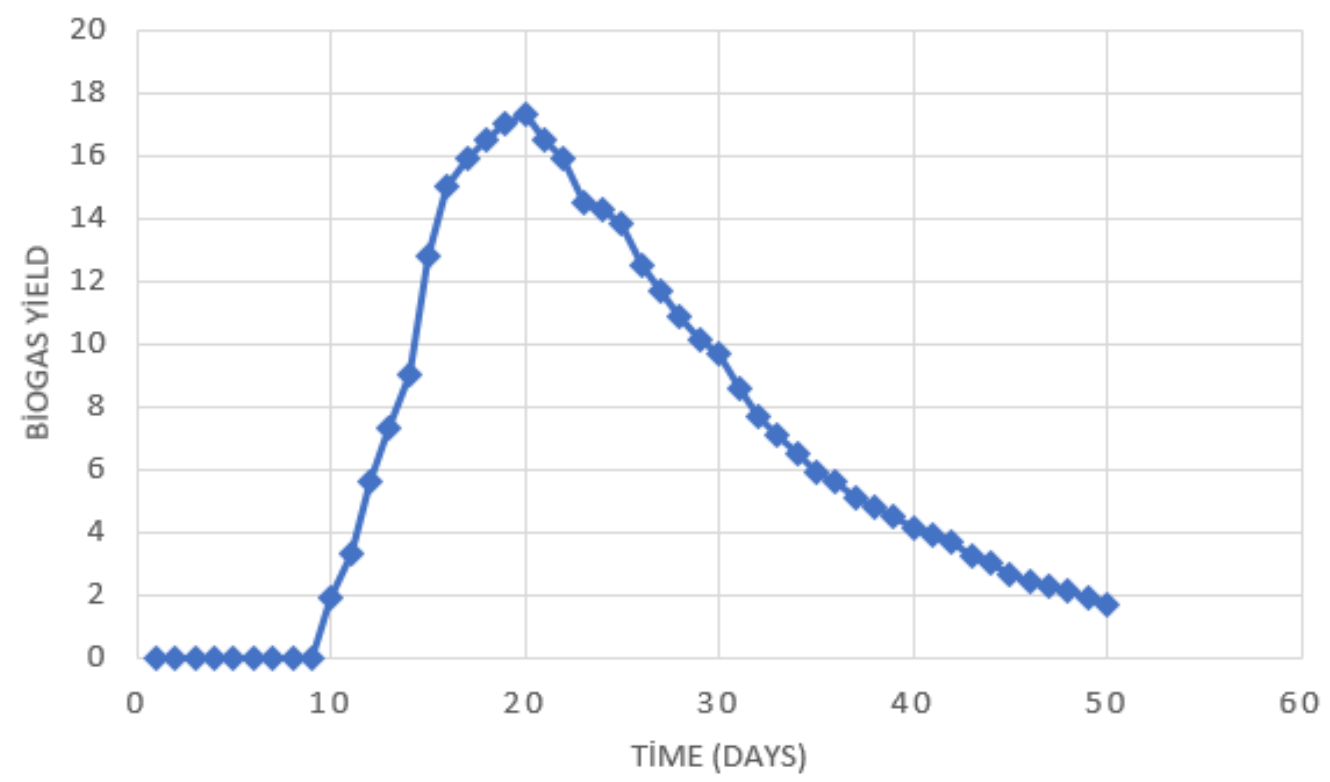

Figure 1. Biogas yield against time

As presented in Figure $\mathbf{2}$ and $\mathbf{3}$, both models have a good fit but the exponential equation had a better simulation than the linear equation with a coefficient of determination of 0.969 .

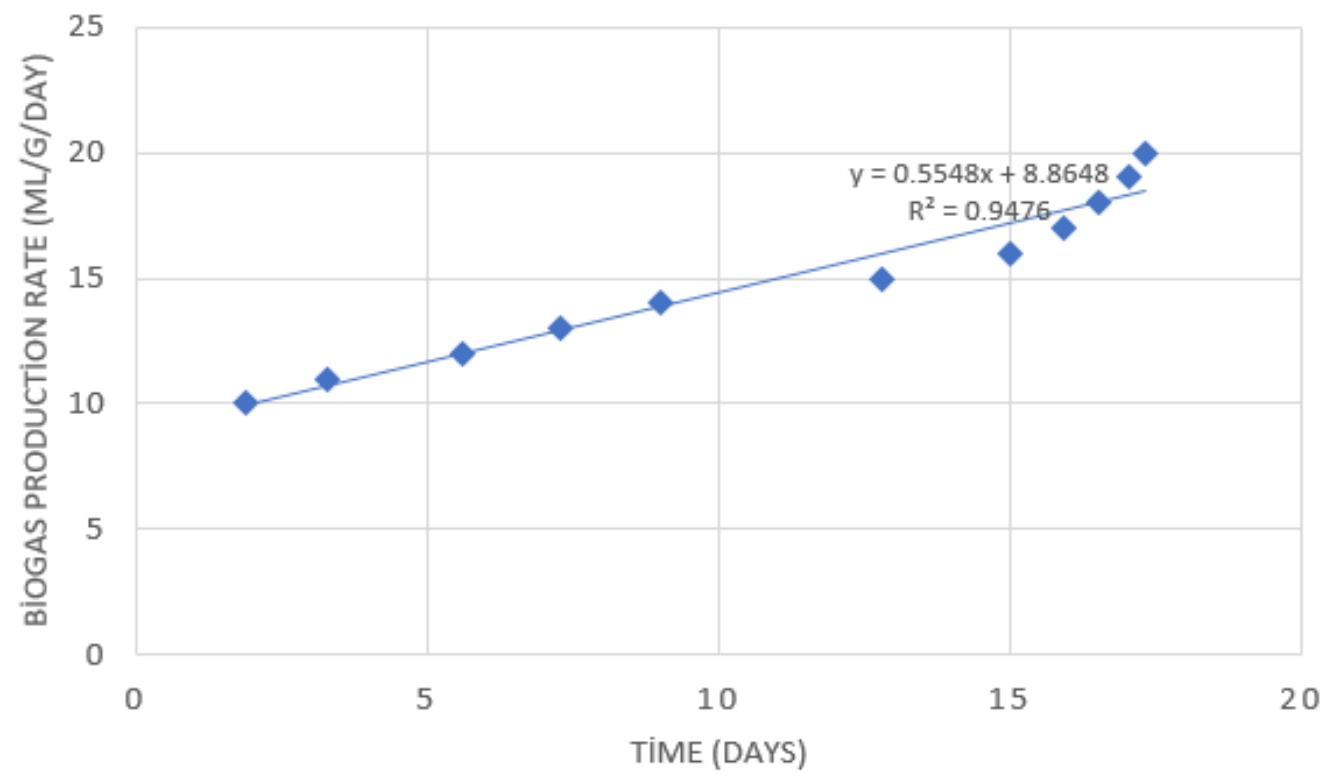

Figure 2. Linear plot of biogas production rate from poultry manure and banana peels in ascending limb 


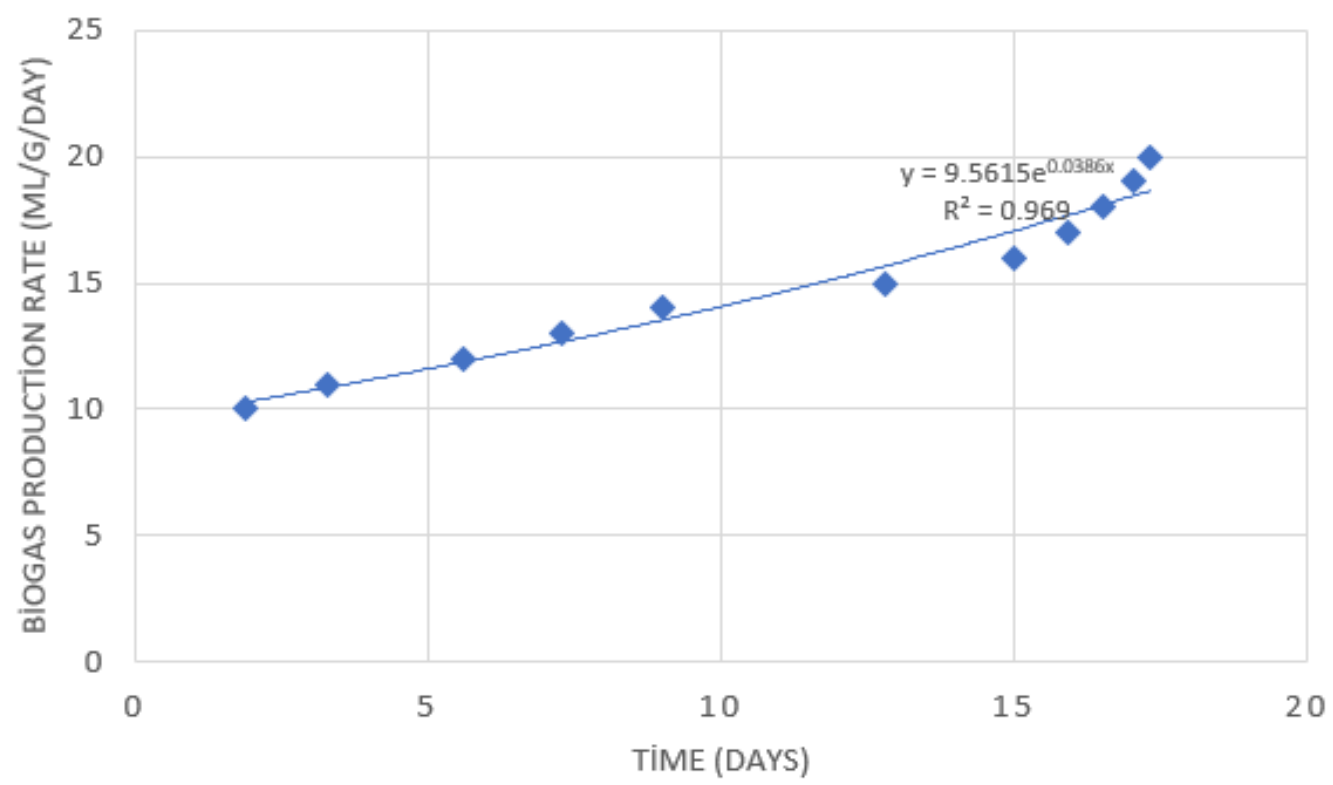

Figure 3. Exponential plot of biogas production rate from poultry manure and banana peels in ascending limb

From Table 3, the linear equation was tested using the first and second order kinetic model, the first order gave a better correlation than the second order with both models significant.

Table 3. Kinetic model summary

\begin{tabular}{ccccc}
\hline Order of reaction & Model & $\mathbf{R}^{\mathbf{2}}$ & Fvalue & Pvalue \\
\hline First & Linear & 0.86 & 55.23 & 0.000 \\
\hline Second & Linear & 0.639 & 15.96 & 0.121 \\
\hline
\end{tabular}

\section{CONCLUSION}

Poultry manure and banana peel as a co-substrate offers an attractive raw material for biogas generation, with an optimal biogas yield of $17.30 \mathrm{ml}$ on the $20^{\text {th }}$ day, it kept producing till the $50^{\text {th }}$ day at a minimal rate. Exponential plot simulated biogas production rate better and the reaction kinetics followed a first order type with a rate constant of 0.121 per ml per day.

\section{REFERENCES}

Al Imam, I. F., Khan, M. Z. H., Sarkar, M. A. R., \& Ali, S. M. (2013). Development of Biogas Processing from Cow dung, Poultry waste, and Water Hyacinth. International Journal of Natural and Applied Science, 2(1), 13-17.

Anushiya, S. (2010). Prospect of Biogas in terms of Socio-Economic \& Environmental benefits to rural communities of Nepal. A case of Biogas Project in Gaikhur VDC of Gorkha District (M.Sc.Thesis).

Budyono, I. N. Widiasa, S. J., \& Sunarso (2001). Increasing Biogas production rate from Cattle manure using Rumen Fluid as Inoculums. International Journal of Basic and Applied Science IJABAS-IJENS, 10, 68-75.

Ekpo, M. A., \& Thomas, N. N. (2007). An investigation of the state of microorganisms and fluted pumpkin (Telfaira occidentalis) in a crude oil impacted garden soil. Nig J Miccobiol, 21, 1571-1577.

Ezeoha, S. L., \& Idike, F. I. (2007). Biogas production potential of cattle paunch manure. Journal of Agricultural Engineering and Technology (JAET), 15, 25-31.

Ghata, D. M., \& Mahanta, P. (2014). Comparison of kinetic models for biogas production rate from saw dust. IJRET, 03(07), $248-254$. https://doi.org/10.15623/ijret.2014.0307042

Gunaseelan, V. N. (1997). Biomass. Bioenergy, (13), 83-114. https://doi.org/10.1016/S0961-9534(97)00020-2

Jorgensen Jacob, P. (2009). Biogas - green energy Faculty of Agricultural Sciences. Aarhus University.

Kaygusuz, K., \& Kaygusuz, A. (2002). Renewable Energy, 25, 431-453. https://doi.org/10.1016/S0960-1481(01)00075-1

Kivais, A. K., \& Mtila, M. (2005). Production of biogas from water hyacinth (Eichorma crssipes) in a two-stage bioreactors. World J. of Microb, Biot. (14), 125-131. https://doi.org/10.1023/A:1008845005155

Kumar S. (2005) Studies on efficiencies of biogas production in anaerobic digesters using water hyacinth and night soil alone as well as in combination. Asian J. Chemistry, (17), 934-939.

Latinwo, G. K., \& Agarry, S. E. (2015). Modelling the kinetics of biogas production from mesophilic anaerobic co-digestion of cow dung with plantain peels. Int. Journal of Renewable Energy Development, 4(1), 55-63. https://doi.org/10.14710/ijred.4.1.55-63 
Maile, I. I., \& Muzenda, E. (2014). Production of biogas from various substrates under anaerobic condition. International Conference on Innovative Engineering Technologies (ICIET 2014), Dec. 28-29, 2014. Bangkok (Thailand)

Matheri, N. A., Belaid, M., Seodigeng, T., \& Ngila, C. J. (2016). Modelling the kinetic of biogas rate from cow dung and grass clippings. Proceedings of the world congress on Engineering 2016 Vol II WCE 2016, June 29-July 1, 2016, London, UK.

Raposo, F., De la Rubia, M., Fernandez Cegri, V. and Borja, R. (2012). Anaerobic digestion of solid organic substrates in batch mode; an overview relating to methane yields and experimental procedurs. Renewable and Sustainably energy reviews, $16,861-877$. https://doi.org/10.1016/j.rser.2011.09.008

Shitophyta, I. M., \& Maryudi (2018) IOP Conf. Series Mater. Sci. Eng. 345012004.

Singhai, V., \& Rai, L. P. (2003). Biogas production from water hyacinth and channel grass used for photodrama; edition of industrial effluents. Bioresour Technol, (86), 221-225. https://doi.org/10.1016/S0960-8524(02)00178-5

Skarstad, K., Steen, H. B., \& Boye, E. (1983). Cell cycle parameters of slowly growing Escherichia coli B, r studied by flow cytometry. J. Bacteriol., 154(2), 656-662. https://doi.org/10.1128/JB.154.2.656-662.1983

Soetart, W., \& Vandamme Erik, J. (2009). Biofuel; Wiley series in renewable resources.

Wilawan, W., Pholchan, P., \& Aggarangsi, P. (2014). Biogas Production from Co-digestion of Pennisetum Pururem cv. Pakchong 1 Grass and Layer Chicken Manure Using Completely Stirred Tank. Energy Procedia, 52, $216-222$. https://doi.org/10.1016/j.egypro.2014.07.072

Yeole, T. Y., \& Ranade, D. R. (1992). Alternative feedtocks for Biogas. In B. Nagamani \& K. Ramasamy (2011), Biogas production technology. An Indian perspective (p. 10-15). Fermentation Laboratory, Department of Environmental Sciences, Tamil Nadu Agricultural University, Combatore 641003 India. 